\title{
MUSEUM AND NEW ART REPRESENTATION IN THE MODERN AGE
}

\author{
Ehsan Shafagh Niloei \\ Master of Science Student, Faculty of Architecture, International Jolfa Branch, Islamic Azad University, \\ Tehran, Iran
}

\begin{abstract}
Vital role of museums play a role in human societies, lasting and promoting cultural phenomena is the purest. Keeper of the few museums of the last generation memorials, in fact, is children's art and history. Each of these objects in the same language of the thousands of languages are spoken the documents, art culture, and history offered. In this paper, a new relationship between art and architecture show how they have been studying. Museums as a mirror for the promotion of intellectual and artistic progress and sustainable development of society act. The method described in this paper analytical and library studies and scientific literature review. Results in this study show new art museum to display the appropriate spaces when you can this powerful functionality highlight the arts show them the proper relationship between art and space are established. That is why architectural transformations, art museum greatly influenced by the dynamics of the new arts and devices used by their representation.
\end{abstract}

Keywords: museum, new art, architectural space

\section{INTRODUCTION}

The museum is the Greek word "museum Yun" means the House of Angels is inspired. In general, the museum refers to the collection of artifacts kept in place or mansion and put on display. Science museum and museology in the nineteenth century, concurrent with the development of concepts and classifications, enter a new phase of its development was now the objects on display, all traditional and industrial products in the fall. Museum as an emerging phenomenon in the art world and a variety of different roles and functions are responsible. Functions including exhibition, preservation, education and research can be outlined and the museums increasingly influential as a social institution and affecting various aspects of modern societies. In the twentieth century museum goes towards a new cultural space to become the kind of mentality. The only duty of protecting other museums collections and their restoration to display open to the public and the application of research to not spend. Museum, cultural center and hosts conferences, different views, libraries, galleries, educational centers, restaurants and drifts wide sales of books, graphics, container and diverse objects.

Looking Museum of Applied Arts, ethnological museum, open air museum, science museum, transportation, post, a variety of games, cheese, salt, straw and so on occur later this century (Karimi, 1995, p. 45). Museums, primarily in the architectural spaces in palaces and hotels and lies collectors were formed, starting this situation. The importance of education's function, their monuments such as the famous architectural design Shink, Van Keynes and Semper, Typology and special architecture and their new structure (Merlin and Choay, 2005, 570) with increasing number of museums, all of them concentrated in urban centers, there is no other possibility. The rapid expansion, upgrade technology, attention to natural areas and rural and expansion of tourism, decentralization of the museum and in this way to have revived movement and use change to create some of the monuments and museums on this matter has been effective. "The so-called museum, the place where the tank is a unique old books and objects and world ... and we can say that the intelligence scale museum and the wisdom and the guilds and Mer'at Salasel is perceived communication, unresolved problems can be resolved here and brought witnesses to the historical data "(Shirazi, 1992, 2).

Art that somehow expresses the artist's deepest perception experiments is in line with the changes of life and mental perceptions, new forms and new takes on. With these developments, the artwork needs are spaces that have been coordinated with the new arts and represent their dynamic nature. As a result, conventional 
architectural spaces to display artwork can only highlight the impressive features of these arts that the proper relationship between artwork and display space they established. Because of changes in architecture, art museums greatly influenced by the dynamics of the new arts and ways of representation they are located. Many studies have been done so far about the new arts. The arts are divided into different categories and characteristics of each category are followed. On the other hand, art museums are also of interest and study architecture. However, there are few studies the relationship between the new arts and art museums in the way research is the result to help the design museum with features tailored to the arts. This article aims at emphasizing the analytical framework for understanding the relationship of new arts and place their views on the contemporary museum architecture should be considered.

\section{THE NEED FOR RESEARCH}

One of the foundations of classification is presentation on the art new space. On this basis, performance art, environmental art, conceptual art, video art, multimedia art and installation art of all kinds of art are, however, conceptual art, wider meaning of art is new and it encompasses. The necessity of a new art museums from the fact that the contemporary art with their own characteristics, part of the history of art form, and museums as cultural institutions supporting the arts in art history of the period and completion of the ring are at the forefront of artistic and other cultural institutions.

\section{MUSEUMS}

Museums in the past were known for their quality and breadth of their collections. In fact, rare objects and archaeological museums, cultural and artistic heritage we were the Iranian Revolutionary Guards. Today, the function of museums has changed considerably.

Museum with fascinating exhibitions and rebuilding and expanding their space and invest in the construction of large buildings, the people attracted to them. 1970s of mega-projects have been completed: the Centre Pompidou in Paris, the Guggenheim Museum in New York, eastern part of the National Gallery of Art in Washington, Louvre Pyramid, the Getty Museum in Los Angeles, the Synsbry National Gallery in London, the Guggenheim Museum in Bilbao, rebuilt a number of museums in Berlin and New Tate Museum in London. Tend to photography, video and environmental art and turn them into insights and sensibilities of today's most pervasive human transporter directly the phenomenon of open museums and facilities they have provided to show this type of work is associated.
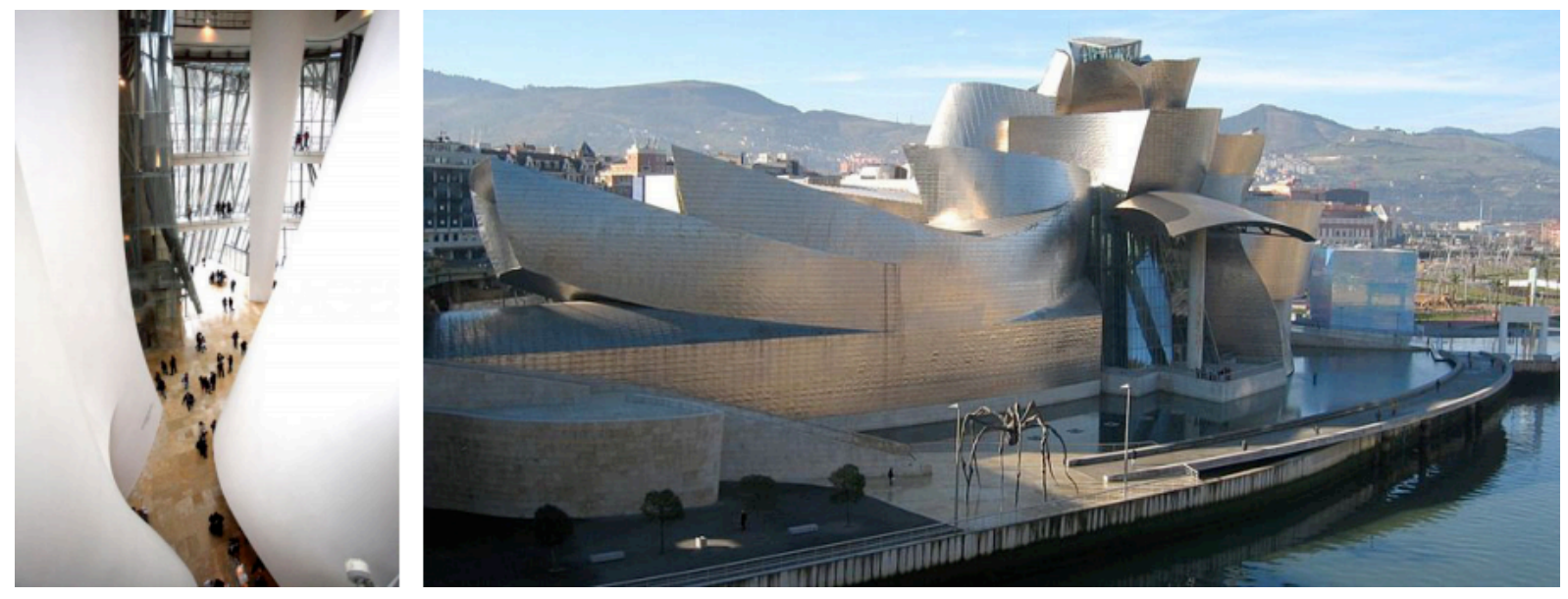

B

A

Figure 1: Outdoor spaces (a) and internal (b) Guggenheim Museum Bilbao, Frank Gehry effect, An example of a museum display space is centered.

From the perspective of Michel Van Perreh, open to the public collections represent a political decision to reduce the gap between experts and non-experts in the field of scientific knowledge for economic reasons, social or ideological. "In France, open plan of Louvre Grand gallery was introduced in 1779. In 1783 in Munich, Germany Bavarian State Collection of signs, Governing Council was opened to the public and Offitsi 
Museum opened in Italy in about 1780. In Vienna, the Austrian capital, Bloodreh Museum was open to all visitors, provided that their footwear is clean. According evil after the French Revolution, the Museum of the necessary institutional became public. Institutional throughout the continent of Europe more or less guaranteed the future "(Bali, 2004: 74). The French Revolution brought about the concept of the museum as a public institution. The institutional responsibility of the government to the country's heritage and responsibility towards the citizens of the museum was included. This concept has been crucial for the development of museums in the nineteenth century. Since the museum is a place that works and samples and other data related to the issues, activities and achievements in science, culture and technology on behalf of the community to gather and protect. A series of exhibition those with the necessary explanations and information and archives of scientific information using a variety of ways and professional and take advantage of them. In addition, the museum held a variety of scientific and educational programs to create and the dissemination of scientific thinking in society (hooper, 1994, 132). "I think cultural development as a social project was first discussed among experts in the world Museum and soon to be one of the areas in meetings and gatherings became International Council of Museums' (ibid: 77). In paragraph 27 of the UN Declaration of Human Rights also referred to the plan: "Everyone has the right freely to participate in the cultural life of the community, to enjoy the arts and in scientific advancement and its benefits are "(Declaration of Human Rights, 2007: 11). "In 1990, 59 percent of museums in the United States, 39 percent of museums in Great Britain, and 35 percent of private museums in Germany. In Italy, 29\% of private museums of which $13 \%$ belonged to the Catholic Church. In the Netherlands, $66 \%$ of museums to foundations or associations and $12 \%$ belonged to the private sector. Even in France, according to conservative estimates, 45 percent are private museums "(Bali, 2004: 78).

Evolution museums in West Europe between 1960 and 2000 have been the same. In Germany, the number of thousand to more than 4 thousand, and in Great Britain and France from about a thousand to more than two thousand reached. In both cases, these official figures are much lower than the actual number of museums, which are believed to be about 3 or 4 thousand. In the Netherlands, the number of museums rose from 400 to 900. In the United States, in the same period the number of two thousand to almost 8 thousand museum is reached. According to a study conducted in the Netherlands, at the beginning of the twentieth century, museum of fine arts was as much as other types of museums. However, today only 20 percent Museum of art, is 80 percent other types of collections in the fall. In the meantime, due to Italy's cultural history - his art is an exception. Art museums in the country make up $31 \%$ of all museums very rich artistic and archaeological heritage are exhibited in the museum. On the other hand, the architecture of museums has become a symbol of modernity and postmodernity. Other museums traditionally not well managed and a network of specialized skills is formed in museums.

\section{HISTORY OF THE EMERGENCE OF MUSEUMS}

English language pronunciation Muse museum in Greece and the name of each of the nine goddesses of the arts is poetry and music in ancient Greece. Pagoda them, a forum for discussion and exchange of ideas among scientists and a place to preserve and display the jewels and valuables, Greek Moueseion called. Muse in English-Italian dictionary, etc. means eyes, thinking, reflection and hesitation is used, Museum, Museu, Museo, Musei, Museet, Muse and the like are described in European languages meaning of the word. High places gods of art, poetry and music that was located on a hill in Athens, the first museum in the history of the museum is named. Museum opening can be a museum "Alexandria of Egypt" that around 280 BC Ptolemy I founded noted. The museum continued for about seven centuries, at the Statue group of scientists, astronomical and surgical instruments and samples of natural products), such as ivory, leather and rare animal skin (to be shown to the people to reflect and training be made. In "Roman" masterpieces of art and valuable works in the palaces, temples and public buildings were kept, and often for the use and enjoyment were collected. In the Middle Ages, churches, rare art objects in order to fill their treasures, collected. Kings, rich and noble private collections gathered according to his power that most of them were the foundation of the future museum. Collect and display works of art organized is one of the innovations Renaissance culture. Great architectural symbols, display from the provision of arts, monuments supplementary Vatican and the "Bramante (Beramante)" in the early sixteenth century design. In the mid-sixteenth century, the word museum is influenced by cultural monuments during the "Hellenic Allexandria" became common. Renaissance museum building is probably the first example of "Como" (Como) for the year 1543 that the word Museum inscribed on its façade. 
The museum first, in terms of form and space of the existing building typology was mimicking. Museum "Uffuzi")) in 1506 "harassment (Vasari)" in Florence, he as a government building was originally anticipated. However, in 1581 it was changed to accommodate the show works of performance art.

It has a wide range of spaces, which later became a model for the museum. Central courtyard surrounded by a portico, long rooms that were open (gallery) and the most important room called Tribune. A cylindrical space with a domed roof with a hole for lightening, reminiscent of ancient Temples, the walls was smothered in red. The color of the eighteenth century British painting exhibitions became common. Museum gallery collection of Renaissance style in about 1615 with the construction of the famous "Statue Arunkel of Earl" (that it plans to Inigo Jones is appointed) go to British.

In the seventeenth century Paris in 1626, saw the opening of the museum's "Natural History" and the UK, overseeing the opening of "Gallery Dulwich" (the "age Soane" which he designed). Museum Ashmolean in "Oxford" was founded in 1683, the first museum that works to accommodate the Orient. 1746 a turning point in the evolution of museums have known, because in that year the French author "La Fonte de Saint-Yenne" new ideas, thoughts and ideas about the museums said. Fundamentalist ideas that stimulates accelerated in museums and four years after London, in 1750 the world's first museum located in the Palace "Luxembourg" was set up. Museums such as "British Museum" in London in 1753 and "Louvre" in Paris of 1793 and the first museum in the Americas in the name of "Museum Charleston" Museum Petersburg Leningrad, Russia in 1764 the first museum in the world and Asia should be outlined. In the nineteenth century, the evolution of the past, while museums, other countries have acted to establish a museum, they were the vanguard of India. Museum has important characteristics of the variety of their topic.

\section{THE OVERALL OBJECTIVES MUSEUMS}

Some general goals for museums can be stated as follows:

1. View and transfer them to works of the past and the future.

2. Evaluation and comparison of historical phenomena, scientific, technical, industrial and artistic past

3. Create and strengthen understanding between nations

4. Understanding and display the peoples and nations of the world culture and civilization

5. upswing and improve the knowledge of students, students, researchers, seniors and other groups

6. attention and creating incentives in different fields of scientific research, cultural and artistic

7. avoid forgetting the local culture (Sadeghpoor Firozabad et al., 2014, 41).

\section{DEFINITION AND HISTORY OF MODERN ART}

New art form of contemporary art is the artist using new media in an effort to find new concepts variety of topics. In this kind of art, the artist informed and unbiased imitation of the past have consciously accept new meanings and messages can be achieved in a new context. New Art As with any new phenomenon has some features that distinguish it from other arts. Artists work in this field with new ideas and different approaches of art benefit in fact, these artists share not the subject. Raw materials or working methods, but their interest and commitment to a more broad view of artistic creation and through this self-discovery is the result of interaction of these elements, personal environment, it made to manufacturer's mental and physical health, as well as artists they are unique (Smagola, 2002, 385). In the last decades of the twentieth century, in particular political circumstances, social and cultural attitudes and practices in relation to art, the art world saw the formation and the development of deep changes in the concept of art and the beauty of it. Such flows are known with the name of the new art is often followed by the younger generation.

\section{THE RELATIONSHIP BETWEEN MODERN ART AND MUSEUM}

One of the most important art museums is the museum typology. There are artists and art styles and periods with different methods and media, museums and audiences, artists and other attractive community, 
informative, fun. With the rise and spread of modern art in the world, museums along with other cultural institutions affecting these flows, space and suitable for classification, presentation and storage provide new art. After understanding, the nature museum of modern art can be compared and examined the relationship between them. The relationship between modern art and the museum is a two-sided relationship. These two new phenomena that human beings are the result of human approaches them. In this regard, thereby museums are the objectives and topics are created. Viewing and maintenance of works of art, particularly ancient and classical art has always been one of the concerns of the curators. But with recent developments in the eighties new museums, especially museums that during the second half of the decade made and different approaches that are more technical and more specialized especially since museums are also actively involved in the field of modern art, it inevitably has to deal with new forms of museum. Size, application, shape and complexity of new museums are the most important characteristics. Taken together, these features result in classification results from the new museums. (Maria, 2003, 11)

\section{REPRESENTATION OF THE NEW ART IN MUSEUM}

New art features distinguish them from other arts. Artists who work in this field with a different outlook, will benefit from the new art. In fact, what these artists share not matter, materials or methods of work, but their interest and commitment to a broader vision of artistic creation and self-discovery (Smagola, 2002, 385). In the opinion of many critics Today, a variety of works of art that have been developed with funds from the artist's individual values, more than faith, shaken represent the views of their creator (Edmund Burke, 2009, $37)$.

One of the special attributes associated with the architecture in a variety of new art created by artists of the century, museum dry out and get out of the works of art in art galleries. Artists of this period, even beyond its art galleries have been introduced to the public and one of their goals to bring the arts into everyday life is new.

The location display, new arts can be divided into five general categories:

- First category: arts such as land art museum to display need not. The origin of this art, go on nature and get away from the trappings of human life and the people running it are generally easy access.

- Second category: arts such as art event their dependence on display at the museum is selectable. This close relationship is with art in everyday life and very quick and unexpected. Arts because the museum is not necessary run this special place.

- Third category: arts such as performance art, the art of placement and arrangement of the pieces needed to display video. Art of placement in close relationship with the museum is because for the finding, we need to have a neutral space. Executive art for display, they need to place the necessary criteria.

- Fourth category: Internet-oriented arts such as interactive art, digital art and art in a global network that can be accessed only in cyberspace. A variety of digital arts and the Internet to realize the need have a certain place and find meaning in cyberspace.

- Fifth category: arts such as video art, interactive art, and virtual reality, both in cyberspace and in the Museum are available. The arts can be exhibited in a place where there is the possibility of implementing them, virtual network or the Internet for viewers are available (Einifar, 2013 8- 7)

\section{THE NEW ART MUSEUM AND VIEW LOCATIONS}

Art that somehow expresses the most profound experiences of conceptual artist, in line with the changes life and human mental perceptions, new and fresh takes shape. In recent decades the arts as a new art and new art, abstract paintings and modern sculpture, digital arts and computer types are included that use new technologies, is on the new find. With these developments, works of art are in need of space coordinated with new art form and represent their dynamic nature. As a result, conventional architectural spaces to display artwork can only affect the ability of the arts to highlight that the proper relationship between artwork and display space they established. Because of changes in architecture, art museums greatly influenced by the dynamics of the new arts and ways of representation they are located. One of the challenges of contemporary 
museums, deliver and maintain new works of art. New art in the second half of the twentieth century began to spread among young artists more popular among artists. The artists with an emphasis on new ideas, creativity and conceptualism works of art, offering a variety of approaches and wide use of the media, seeking relief from the shackles of modern art. New based on aversion Museum, Mira art common use of the readyinterference environment artist at work, audience participation in the creation of art and the use of new technologies is based. This art with its unique features, form part of the history of art and provide preservation and the same physical space of the museum or need. Museum of Modern Art Museums are important species, which provides a platform to display works of contemporary artists, and they challenged the beginning of new art museums to nature of these returns. According to these definitions, conventional inherent feature of the museum storage and presentation of objects and works while the works of new art museum than to escape, Art Mira, high dependence on the environment and actively participating audience as part of their orientation effect. This contrasts with fixed layout museum features collections, necessary logical connection between subject and sets, lighting, limitation of time and space to show works imbalance rise to the challenge and new art museum.

\section{CONCLUSION}

This article seeks to identify research challenges in dealing with works of modern art museums have been prepared. Factors affecting the implementation of the new art museum There are museums, including architectural features, the media, the audience works and the type of arrangement outlined. The need for common audience is at the presentation of new art museum and some species such as brick paperboard art. What is on offer, preservation and presentation of new works of art in museums is important. Museums and curators dealing with these works trying to identify the main challenges facing museums with works of modern art and try overcome them hanging this article. As the effect of the environment and location is important to the concept, as well as some works with the environment this new arts and important they are sometimes able to provide preferred locations artist museum space is not new. Research and study works of modern art, is effective in the clear up some ambiguities. This is despite research resources, experts and related ongoing relationship with artists and cultural institutions is possible.

\section{REFERENCES}

Edmund Burke Feldman (2009), a variety of visual experiences, translation Parviz Marzban, Soroush Publications, Tehran.

Smagola, Hoardjy (2002), contemporary trends in visual arts, translation Farhad Ghabraee, the Cultural Research Bureau in Tehran

Universal Declaration of Human Rights (2007), the United Nations Department of Public Information, United Nations Information Centre, Tehran.

Ayatollah Shirazi, B. (1992) "The image of museums", Journal of museums, No. 12, Tehran, Iran Cultural Heritage Organization

Bali, Catherine (2004), "democratization and institutional change: the dilemma of museums today", the translation of Omid Nick Farjam, Globalization and art magazine, edited by F. Sasanian art Research Center, 71-89.

Pakbaz, Rooin (2004), Encyclopedia of Art, Contemporary Culture, Tehran

Sadeqpoor Firozabad, A., Mir Azizi, Mahmood, Khalil Zadeh Moghaddam, M. (2014), museum management, publishing, Tehran

Einifar, AR, Keypoor, S., (2013), analyzes the relationship between practices and representations of places views on the new arts magazine of Fine Arts Architecture, Volume 18, Issue 1, pp. 14-5

Karimi, A (1995) "Eco Museum, the Museum of Man and Ecology" magazine museums, Tehran, Iran Cultural Heritage Organization

Linton, Norbert, modern art, translated by Ali Ramin, Reed Publishing, printing in 2003.

Merlin, Pierre et Françoise Choay ( 2005), Dictionnaire de l'urbanisme et de l'aménagement, Edition Quadrige, Paris. 